\title{
The impact of socioeconomic factors on the healthcare costs of people living with HIV in Turkey
}

\author{
Hülya Özkan Özdemir', Selma Tosun ${ }^{1}$, Fatma Nur Karaman Kabadurmuş² and Durmuş Özdemir
}

\begin{abstract}
Background: This study addresses an important field within HIV research, the impact of socioeconomic factors on the healthcare costs of people living with HIV/AIDS (PLHIV). We aimed to understand how different socioeconomic factors could create diverse healthcare costs for PLHIV in Turkey.

Methods: Data were collected between January 2017 and December 2017. HIV-positive people attending the clinic who had been referred to the national ART programme from January 1992 until December 2017 were surveyed. The questionnaire collected socioeconomic data. The cost data for the same patients was taken from the electronic database Probel Hospital Information Management System (PHIMS) for the same period. The PHIMS data include costs for medication (highly active antiretroviral therapy or HAART), laboratory, pathology, radiology, polyclinic, examination and consultation, hospitalisation, surgery and intervention, blood and blood products, supplies and other costs. Data were analysed using STATA 14.2 to estimate the generalised linear model (GLM).

Results: The findings of our GLM indicate that age, gender, marital and parental status, time since diagnosis, employment, wealth status, illicit drug use and CD4 cell count are the factors significantly related to the healthcare cost of patients. We found that compared with people who have AIDS (CD4 cells $<200 \mathrm{cells} / \mathrm{mm}^{3}$ ), people who have a normal range of CD4 cells $\left(\geq 500\right.$ cells $\left./ \mathrm{mm}^{3}\right)$ have $\$ 1046$ less in expenditures on average. Compared to younger people (19-39 years), older people $(\geq 55)$ have $\$ 1934$ higher expenditures on average. Costs are $\$ 644$ higher on average for married people and $\$ 401$ higher on average for people who have children. Healthcare costs are $\$ 518$ and $\$ 651$ higher on average for patients who are addicted to drugs and who use psychiatric drug(s), respectively. Compared to people who were recently diagnosed with HIV, people who were diagnosed $\geq 10$ years ago have $\$ 743$ lower expenditures on average.
\end{abstract}

Conclusion: Our results suggest that in addition to immunological status, socioeconomic factors play a substantial role in the healthcare costs of PLHIV. The key factors influencing the healthcare costs of PLHIV are also critical for public policy makers, healthcare workers, health ministries and employment community programs.

Keywords: HIV/AIDS, PLHIV, Economic and social factors, Healthcare costs, Turkey

\footnotetext{
* Correspondence: durmus.ozdemir@yasar.edu.tr

${ }^{2}$ Department of Economics, Yaşar University, Üniversite Caddesi No: 37-39, 35040 Bornova, İmir, Turkey

Full list of author information is available at the end of the article
}

(c) The Author(s). 2020 Open Access This article is licensed under a Creative Commons Attribution 4.0 International License, which permits use, sharing, adaptation, distribution and reproduction in any medium or format, as long as you give appropriate credit to the original author(s) and the source, provide a link to the Creative Commons licence, and indicate if changes were made. The images or other third party material in this article are included in the article's Creative Commons licence, unless indicated otherwise in a credit line to the material. If material is not included in the article's Creative Commons licence and your intended use is not permitted by statutory regulation or exceeds the permitted use, you will need to obtain permission directly from the copyright holder. To view a copy of this licence, visit http://creativecommons.org/licenses/by/4.0/. The Creative Commons Public Domain Dedication waiver (http://creativecommons.org/publicdomain/zero/1.0/) applies to the data made available in this article, unless otherwise stated in a credit line to the data. 


\section{Background}

Although, the life expectancy of people living with HIV/ AIDS (PLHIV) has increased substantially since the introduction of antiretroviral treatment (ART), current HIV data trends show that a large number of people are still infected and living with HIV in Turkey and in the world, [1-7].

Following these developments, the health care cost of PLHIV is rising and the issue has become increasingly important. Due to the high costs, the incumbent Turkish government currently introduced a cost cutting measure such as the foreign country originated HIV infections are no longer supported with free medical care. This measure has been criticized heavily. The health care costs of PLHIV are classified in a number of different groups in the Probel Hospital Information Management System (PHIMS) [8]. PHIMS data include costs for medication (highly active antiretroviral therapy or HAART), laboratory, pathology, radiology, polyclinic, examination and consultation, hospitalisation, surgery and intervention, blood and blood products, supplies and other costs such as nursing and care services. All state hospitals and number of university hospitals in Turkey use this electronic system to store and share administrative, financial and medical information on a daily basis.

Our study intending to help on cost cutting measures to optimize both sides benefits.

Studies analysing the link between the social and economic factors and the prevalence of a disease are limited in the literature $[5,6,9-11]$. Therefore, the objective of our paper addresses an important field within HIV research, the impact of socioeconomic factors on the healthcare costs of PLHIV in Turkey. To investigate the factors that determine healthcare costs of PLHIV, we considered demographic and socioeconomic characteristics (gender, age, education, marital status, parental status, employment, and wealth), risk factors for HIV infection (smoking, alcoholism, drug addiction, psychiatric drug use, sexual orientation: lesbian, gay, bisexual, and transgender (LGBT) or heterosexual), CD4 T-cell count (at the time of diagnosis), and time since diagnosis (the difference between 2017 and the year when HIV infection was first diagnosed).

Often research in this area focusses on one single issue such as the CD4 cell count and cost or age and cost or employment and cost for PLHIV. There has been no study covering all medical and socioeconomic factors affecting these health care costs. This research not only links the whole set of parameters, but also clarifies the impact of each parameter on the healthcare costs for PLHIV. Different socioeconomic factors can create diverse healthcare costs for PLHIV.
ART improves the quality of life for these patients, yet there are serious cost diversities among PLHIV. The main aim of this study was to clarify the key socioeconomic factors that affect healthcare costs for PLHIV. This may help to plan for future expenditure requirements and to suggest strategies for improving the efficiency of HIV treatment programs.

\section{Methods}

This study is carried out at Izmir Bozyaka Education and Training Hospital, Department of Infectious Diseases and Clinical Microbiology (Izmir, Turkey) where we have a cohort of 153 PLHIV. This cohort characteristics are the same as the whole country and represent the Turkish data in gender and all other sociodemographic factors [4]. Following the ethical committee approval, this study used clinical data recorded by patients and healthcare professionals in the outpatient clinic. In order to determine socioeconomic measures, patients were interviewed face-to-face and the interview questions are the same as the earlier study of Özdemir et.al [9].

Cost data was taken from the electronic database Probel Hospital Information Management System (PHIMS) for the fiscal year 2017 [8]. The data include costs for medication (HAART), laboratory, pathology, radiology, polyclinic, examination and consultation, hospitalisation, surgery and intervention, blood and blood products, supplies and other costs such as nursing and care costs.

Table 1 describes the variables used in our analyses.

Table 2 shows a comparison of total healthcare costs by patient subgroups. Patients with low CD4 T-cell counts and who are female, older, married and have children, who smoke and drink heavily, who are addicted to drugs, who have low-income and education are associated with higher healthcare costs. More specifically, the average healthcare cost is highest (\$5422.99) for patients with CD4 cell counts of less than 200 cells $/ \mathrm{mm}^{3}$. The average cost decreases to $\$ 4170.64$ as CD4 cell count increases to 200-499 cells/ $\mathrm{mm}^{3}$ and is lowest (\$3964.49) for patients with CD4 cell count $\geq 500$ cells/ $\mathrm{mm}^{3}$. Female patients have a mean healthcare cost of $\$ 4689.55$ as compared to $\$ 4150.25$ for males. For patients who are 55 or older, average annual healthcare cost is $\$ 5041.74$, whereas it is $\$ 4820.45$ for the $40-54$ age group and $\$ 3850$ for the 19-39 age group. The average healthcare cost is also higher for married people (\$4985.74) compared to singles (\$3901.95). Looking at healthcare costs of patients with respect to wealth groups, we see that patients in the lowest income group ( $<$ Min wage) have the highest costs on average (\$4558.78). Other wealth groups with incomes $\geq$ Min wage and $\geq 2 x$ Min wage have average costs of $\$ 4174.21$ and $\$ 4078.55$, respectively. In addition, patients who have children have higher average costs $(\$ 4987.97)$ than patients with no 
Table 1 Definition of Variables

\begin{tabular}{ll}
\hline VARIABLE & DEFINITION \\
\hline EXPENDITURES & Total annual healthcare expenditures for 2017 (nominal $\$)$. \\
GENDER & Gender of the patient. Dummy variable $=1$ if the patient is Female. \\
AGE & Age of the patient. Three categories: $1(19-39), 2(40-54), 3(>=55)$. \\
WEALTH & Welfare status of the patient (measured by minimum wage, including non-wage income, family support, \\
& transfer payments, etc.). Three categories: 1 (lower than minimum wage), 2 (higher than minimum wage), \\
& 3 (higher than double minimum wage). \\
EDUCATION & Education level of the patient. Two categories: 1 (Middle school or less), 2 (High school and university). \\
EMPLOYMENT & Employment status. Dummy variable $=1$ if the patient is employed, 0 otherwise. \\
MARITAL STATUS & Marital status. Dummy variable $=1$ if the patient is married. \\
CHILD & Parental status. Dummy variable $=1$ if the patient has at least 1 child. \\
SMOKE & Smoking status. Dummy variable $=1$ if the patient is a smoker. \\
ALCOHOL & Alcohol use. Dummy variable $=1$ if the patient drinks alcohol. \\
DRUG ADDICTION & Drug addiction status. Dummy variable $=1$ if the patient is addicted to drugs. \\
PSYCH DRUG & Psychiatric drug use. Dummy variable $=1$ if the patient is taking psychiatric drugs. \\
SEX ORIENTATION & Sex orientation. Dummy variable $=1$ if patient is heterosexual, 0 if identifies as LGBT. \\
CD4 & CD4 T-cell count. Three categories: $1(<200$ cells/mm3), 2 (200-499 cells/mm3), 3 ( $\geq 500$ cells/mm3). \\
TIMEDIAG & Duration of treatment. Dummy variable $=1$ if the patient was diagnosed $\geq 10$ years ago, 0 otherwise. \\
\hline
\end{tabular}

children (\$3788.93). The average healthcare cost is higher for smokers (\$4383.91) compared to those who don't smoke (\$3985.82). Alcohol users also have a higher average healthcare cost $(\$ 4383.90)$ than non-users (\$4186.51). Education level of patients are divided into two sub-groups. Namely, 'Middle school or less' and 'High school and university'. The average healthcare cost is higher for the former group (\$4707.58) compared to the latter one (\$3918.26). Patients who are employed have higher healthcare cost $(\$ 4306.74)$ compared to employed patients (\$4083.07). Patients who identify themselves as LGBT (lesbian, gay, bisexual and transgender), have higher (\$4503.50) average healthcare cost than heterosexual patients (\$3982.73). Lastly, the average healthcare cost for patients who were diagnosed $\geq 10$ years ago is higher $(\$ 4291.69)$ than the cost for patients who were diagnosed more recently (\$4220.34).

Our dependent variable measures total annual health care expenditures for 2017, measured in nominal US dollars. Fig. 1 shows that the distribution is left-skewed, and not symmetric. ${ }^{1}$

Although our data is not highly skewed, we avoided using ordinary least squares (OLS). Instead, we used generalised linear models (GLM) following Deb and Norton [12]. to relax the OLS assumptions of homoscedasticity and normality. First introduced by Nelder and Wedderburn [13], the GLM generalises the linear model

\footnotetext{
${ }^{1}$ For the sample, skewness $=-0.16$ and kurtosis $=2.4$. We have also used Skewness and Kurtosis Test for normality after fitting a linear model. The null hypothesis which states that the data follow a normal distribution is rejected at a $5 \%$ significance level.
}

and specifies the relationship between the observed response variable and some number of covariates. The GLM has two components: a link function, which links the expected value of the outcome to the linear predictor comprising the regression coefficients; and a variance function, which relates the variance as a function of the mean and is specified using the name of a particular member distribution of the exponential family [14].

To describe the form of the GLM, we first start with the classical linear model which can be summarized as:

$$
E(Y)=\mu \text { where } \mu=x \beta .
$$

The components of $\mathrm{Y}$ are independent normal variables with constant variance $\sigma^{2}$. To generalize eq. (1), a three-part specification can be used:

(1) The random part: The components of $Y$ have independent normal distributions with $E(Y)=\mu$ and constant variance $\sigma^{2}$.

(2) The systematic component: covariates $x_{1}, x_{1}, \ldots, x_{p}$ produce a linear predictor $\eta$ given by

$$
\eta=\sum_{j=1}^{p} x_{i j} \beta_{j}
$$

(3) The link between the random and the systematic components:

$$
\mu=\eta
$$

If we write $\eta_{i}=g\left(\mu_{i}\right)$, then $g($.$) is the link function and$ Y F (distribution, eg., normal, binomial, Poisson, etc.). In this formulation, classical linear models have a 
Table 2 Baseline characteristics of participants ( $n=153$, cost in \$)

\begin{tabular}{|c|c|c|c|}
\hline PATIENT TYPE & Mean Cost (\$) & Std. Dev. & Freq. \\
\hline \multicolumn{4}{|l|}{ GENDER } \\
\hline Male & 4150.25 & 2248.05 & 131 \\
\hline Female & 4689.55 & 1331.37 & 22 \\
\hline \multicolumn{4}{|l|}{ AGE } \\
\hline $19-39$ years & 3850.03 & 2177.93 & 98 \\
\hline 40-54 years & 4820.45 & 2081.52 & 35 \\
\hline$\geq 55$ years & 5041.74 & 1666.04 & 20 \\
\hline \multicolumn{4}{|l|}{ WEALTH } \\
\hline$<$ Min wage & 4558.78 & 1826.99 & 35 \\
\hline$\geq$ Min wage & 4174.21 & 2252.34 & 63 \\
\hline$\geq 2 x$ Min wage & 4078.55 & 2221.23 & 55 \\
\hline \multicolumn{4}{|l|}{ CD4 } \\
\hline$<200$ cells $/ \mathrm{mm}^{3}$ & 5422.99 & 1883.97 & 19 \\
\hline 200-499 cells/ mm $\mathrm{mm}^{3}$ & 4170.64 & 2112.31 & 61 \\
\hline$\geq 500$ cells $/ \mathrm{mm}^{3}$ & 3964.49 & 2159.23 & 73 \\
\hline \multicolumn{4}{|l|}{ SMOKING } \\
\hline No & 3985.82 & 2085.15 & 60 \\
\hline Yes & 4383.91 & 2180.40 & 93 \\
\hline \multicolumn{4}{|l|}{ ALCOHOL USE } \\
\hline No & 4186.51 & 1970.35 & 121 \\
\hline Yes & 4383.90 & 2740.54 & 32 \\
\hline \multicolumn{4}{|l|}{ DRUG ADDICTION } \\
\hline No & 4167.50 & 2066.87 & 123 \\
\hline Yes & 4475.01 & 2465.13 & 30 \\
\hline \multicolumn{4}{|l|}{ PSYCHIATRIC DRUG USE } \\
\hline No & 4144.39 & 2142.92 & 135 \\
\hline Yes & 4853.35 & 2119.43 & 18 \\
\hline \multicolumn{4}{|l|}{ EDUCATION } \\
\hline Middle school or less & 4707.58 & 2144.43 & 60 \\
\hline High school and university & 3918.26 & 2099.81 & 93 \\
\hline \multicolumn{4}{|l|}{ EMPLOYMENT } \\
\hline Unemployed & 4083.07 & 2023.49 & 54 \\
\hline Employed & 4306.74 & 2215.28 & 99 \\
\hline \multicolumn{4}{|l|}{ MARITAL STATUS } \\
\hline Single & 3901.95 & 2071.78 & 107 \\
\hline Married & 4985.74 & 2144.35 & 46 \\
\hline \multicolumn{4}{|l|}{ SEXUAL ORIENTATION } \\
\hline LGBT & 4503.50 & 1877.71 & 72 \\
\hline Heterosexual & 3982.73 & 2342.59 & 81 \\
\hline \multicolumn{4}{|l|}{ HAVE CHILDREN } \\
\hline No & 3788.93 & 2151.65 & 97 \\
\hline Yes & 4987.97 & 1926.85 & 56 \\
\hline \multicolumn{4}{|l|}{ TIME SINCE DIAGNOSIS } \\
\hline$<10$ years & 4220.34 & 2184.93 & 137 \\
\hline$\geq 10$ years & 4291.69 & 1832.35 & 16 \\
\hline
\end{tabular}

Abbreviations: Min wage minimum wage, CD4 CD4 T-cell count, LGBT lesbian, gay bisexual and transgender, Std. Dev standard deviation, Freq. frequency
Gaussian (Normal) distribution in the random part and the identity function for the link component [15]. To estimate the GLM model, we used Newton-Raphson (maximum likelihood) optimization. All analyses were performed in STATA 14.2.

As explained in the preceding paragraphs, constructing the GLM involves selecting a variance function and an appropriate link function. We used common specification tests to make these choices. We first used the BoxCox test [16] to determine whether our dependent variables needed any transformation in order to have a symmetric distribution. We did the Box-Cox test in two ways, with and without controlling for covariates. The test results showed that the linear, log, and multiplicative inverse specifications are strongly rejected. Combining these with what Fig. 1 reveals about our cost data, we concluded that our cost variable does not need any transformation.

Next, we proceeded with the choice of the distribution family. We used a modified Park test [17-19] after running a GLM with gamma family and log link. The procedure involves computing the mean (expected value) and variance (squared error) for each observation and then predicting the squared error as a function of the expected value. The coefficient on the expected value indicates distribution. If the value is close to 0.0 , it indicates a Gaussian family in which the variance is constant. If the value is close to 1.0 , it indicates a Poisson-like family in which variance is equal (or proportional) to the mean. A value of 2.0 or 3.0 indicates a Gamma (variance is proportional to the mean squared) and inverse-Gaussian (variance is proportional to the cube of the mean) distribution, respectively [19]. Our estimated coefficient was equal to 0.87 , therefore our sample follows Poisson distribution.

As Glick et al. [19] point out, misspecification of family may result in efficiency losses, but it does not affect consistency as long as the link function is correctly specified. The power link has an important role in assessing the fit of models. It allows one to generate a wide variety of links. For example, power $=1$, power $=0$, and power $=$ -1 corresponds to the identity link, the log link and the reciprocal link, respectively [14]. To find the optimal link, we compared deviance and log-likelihood values and AIC and BIC statistics. Moreover, we implemented Pregibon's link test [20] which evaluates the linearity of the response on the scale of estimation. The test assesses whether the coefficient on the squared term is significantly different from zero. We evaluated the power links in increments of 0.1 between -2 and 2 to choose the most appropriate link [14]. These statistics are presented in Table 3 for a selected set of power links. We do not report the statistics for all power links in order to ease presentation. Log-likelihood, deviance, AIC and BIC 


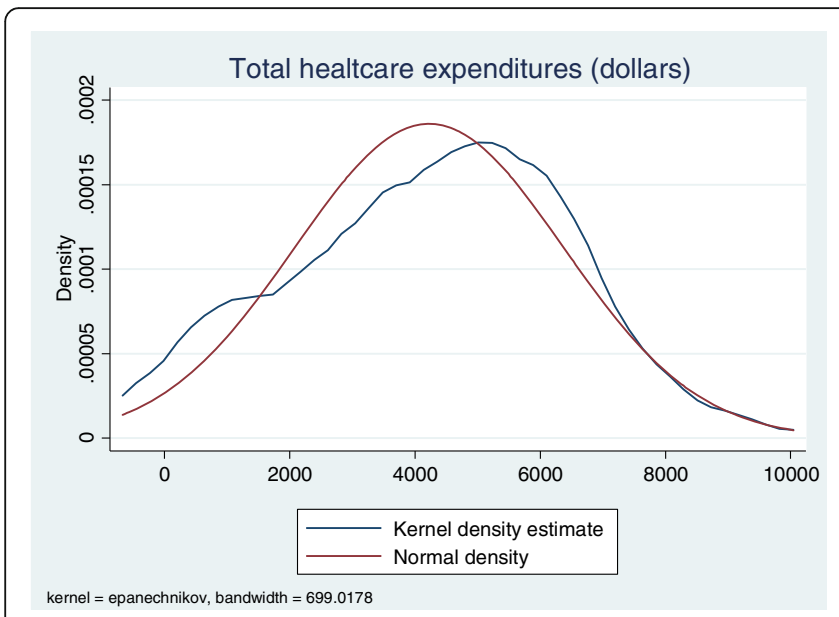

(a)

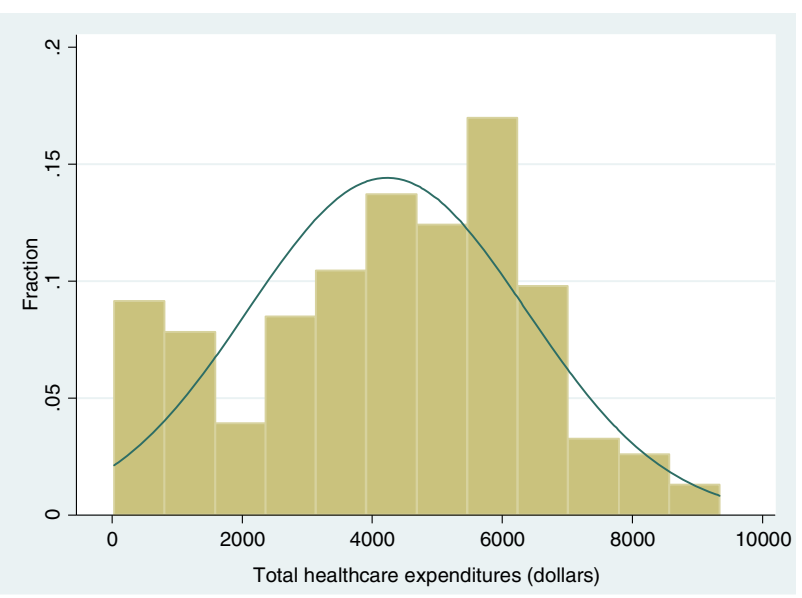

(b)

Fig. 1 Distribution of total healthcare costs

statistics all suggest to choose power link (1.4). However, as Glick [21] argues, the first four statistics are not sufficient alone to identify the appropriate link function. Thus, we proceed and choose the optimal link as (1.3), in line with the results of Pregibon's link test. Moreover, there is not much variation in magnitudes of the four statistics for power link (1.3) and power link (1.4).

\section{Results}

Table 4 reports our GLM results for Poisson distribution and power link (1.3), which is the most appropriate model based on the aforementioned criteria. Incremental effects are reported in column 2 of Table 4. As a robustness check, we have also presented results for identity and log links in Appendix Table 5.

Incremental effects (marginal effects for categorical independent variables) show how the probability of outcome changes given a unit change in the value of the categorical variable. We calculate these as average marginal effects (AMEs). Thus, the marginal effect is first calculated for each individual with their observed levels of covariates. These values are then averaged across all individuals. For the interpretation of AMEs for Poisson regression GLM, we followed Hardin and Hilbe [14].

The incremental effects reported in Table 4 reveal that age, gender, employment status, wealth and CD4 count are the most important factors in determining the healthcare costs of PLHIV. This shows that the individual characteristics of patients are significantly related to costs.

As expected, a better health status of the patient, measured by $\mathrm{CD} 4$ cell count, decreases healthcare costs. We found that compared with people who have AIDS (CD4 cells $<200$ cells $/ \mathrm{mm}^{3}$ ), people who have a normal range of CD4 cells ( $\geq 500$ cells $/ \mathrm{mm}^{3}$ ) have $\$ 1046$ less in expenditures on average (Table 4, column 2). This result is in agreement with the findings of Dube et al. [23] who conducted a systematic review of predictors of HIV infection and argued that early diagnosis and earlier use of therapies improve the effectiveness of treatment and thus reduce healthcare costs.

Demographic variables include age, gender, marital and parental status. Age has the largest effect on costs. Compared to younger people (19-39 years), older people ( $\geq 55$ years) have $\$ 1934$ higher expenditures on average. This result matches those observed in earlier studies. As

Table 3 Optimal Link Selection

\begin{tabular}{|c|c|c|c|c|c|c|c|c|c|}
\hline & $\begin{array}{l}\text { POWER } \\
(-1)\end{array}$ & $\begin{array}{l}\text { POWER } \\
(-0.5)\end{array}$ & $\begin{array}{l}\text { POWER } \\
\text { (0) }\end{array}$ & $\begin{array}{l}\text { POWER } \\
(0.5)\end{array}$ & $\begin{array}{l}\text { POWER } \\
\text { (1) }\end{array}$ & $\begin{array}{l}\text { POWER } \\
(1.1)\end{array}$ & $\begin{array}{l}\text { POWER } \\
(1.2)\end{array}$ & $\begin{array}{l}\text { POWER } \\
(1.3)\end{array}$ & $\begin{array}{l}\text { POWER } \\
(1.4)\end{array}$ \\
\hline $\mathrm{AIC}$ & 1123 & 1114 & 1104 & 1092 & 1077 & 1073 & 1070 & 1066 & 1061 \\
\hline $\mathrm{BIC}$ & 169,561 & 168,261 & 166,695 & 164,832 & 162,532 & 161,992 & 161,414 & 160,793 & 160,137 \\
\hline Log-likelihood & $-85,879$ & $-85,229$ & $-84,446$ & $-83,514$ & $-82,364$ & $-82,094$ & $-81,805$ & $-81,495$ & $-81,167$ \\
\hline Deviance & 170,240 & 168,940 & 167,374 & 165,511 & 163,211 & 162,671 & 162,093 & 161,472 & 160,816 \\
\hline $\begin{array}{l}\text { Pregibon's test, } \\
\text { P-value } \\
\text { for squared term }\end{array}$ & 0.178 & 0.305 & 0.546 & 0.323 & 0.421 & 0.475 & 0.626 & 0.906 & 0.754 \\
\hline
\end{tabular}

Abbreviations: AIC Akaike information criterion, BIC Bayesian information criterion. Initial values were not feasible to fit GLM for power $\geq 1.5$. Power links greater than 1 are usually appropriate for data having a response with a sharp increase of values (Hardin and Hilbe, 2018) 
Table 4 Generalised linear model (GLM) results

\begin{tabular}{|c|c|c|c|c|}
\hline \multirow[b]{2}{*}{ VARIABLES/LINK ${ }^{b}$} & \multicolumn{3}{|l|}{$(1)^{a}$} & \multirow{2}{*}{$\begin{array}{l}\text { (2) } \\
\text { Incremental Effects }\end{array}$} \\
\hline & POWER (1.3) & $\% 95$ Confidence Interval & & \\
\hline \multirow[t]{2}{*}{ CD4 (200-499 cells/mm³) } & $-14,556.84^{* * *}$ & $-15,199.1$ & $-13,914.6$ & $-898.1^{* * *}$ \\
\hline & -327.678 & & & -19.83 \\
\hline \multirow[t]{2}{*}{ CD4 ( $\geq 500$ cells $\left./ \mathrm{mm}^{3}\right)$} & $-16,868.45^{* * *}$ & $-17,503.1$ & $-16,233.8$ & $-1046^{* * *}$ \\
\hline & -323.80 & & & -19.59 \\
\hline \multirow[t]{2}{*}{ Wealth ( $\geq$ min wage) } & $-21,868.29^{* * *}$ & $-22,411.3$ & $-21,325.3$ & $-1365^{* * *}$ \\
\hline & -277.05 & & & -17.08 \\
\hline \multirow[t]{2}{*}{ Wealth ( $\geq 2 x$ min wage) } & $-20,391.69^{* * *}$ & $-20,940.9$ & $-19,842.5$ & $-1268^{* * *}$ \\
\hline & -280.21 & & & -17.24 \\
\hline \multirow[t]{2}{*}{ Employment (employed) } & $22,637.573^{* * *}$ & $22,206.9$ & $23,068.25$ & $1482^{* * *}$ \\
\hline & -219.74 & & & -14.93 \\
\hline \multirow[t]{2}{*}{ Education (high school \& university) } & $911.83^{* * *}$ & 512.04 & 1311.62 & $58.24^{* * *}$ \\
\hline & -203.98 & & & -13.04 \\
\hline \multirow[t]{2}{*}{ Alcohol (yes) } & $1439.45^{* * *}$ & 996.98 & 1881.92 & $91.65^{* * *}$ \\
\hline & -225.75 & & & -14.34 \\
\hline \multirow[t]{2}{*}{ Smoke (yes) } & $7150.11^{* * *}$ & 6780.94 & 7519.27 & $458.0^{* * *}$ \\
\hline & -188.35 & & & -12.12 \\
\hline \multirow[t]{2}{*}{ Psychiatric drug (yes) } & $10,415.17^{* * *}$ & 9844.42 & $10,985.91$ & $651.3^{* * *}$ \\
\hline & -291.20 & & & -17.87 \\
\hline \multirow[t]{2}{*}{ Drug addiction (yes) } & $8225.30^{* * *}$ & 7755.71 & 8694.90 & $518.1^{* * *}$ \\
\hline & -239.59 & & & -14.91 \\
\hline \multirow[t]{2}{*}{ Sexual orientation (heterosexual) } & $-575.12^{* * *}$ & -983.17 & -167.06 & $-36.69^{* * *}$ \\
\hline & -208.20 & & & -13.28 \\
\hline \multirow[t]{2}{*}{ Age (40-54) } & $14,638.10^{* * *}$ & $14,169.67$ & $15,106.53$ & $932.0^{* * *}$ \\
\hline & -238.10 & & & -15 \\
\hline \multirow[t]{2}{*}{ Age $(\geq 55)$} & $31,475.19^{* * *}$ & $30,741.65$ & $32,208.73$ & $1934^{* * *}$ \\
\hline & -374.26 & & & -22.18 \\
\hline \multirow[t]{2}{*}{ Gender (female) } & $13,398.90^{* * *}$ & $12,782.68$ & $14,015.13$ & $835.1^{* * *}$ \\
\hline & -314.41 & & & -19.18 \\
\hline \multirow[t]{2}{*}{ Marriage status (married) } & $10,222.66^{* * *}$ & 9720.721 & $10,724.59$ & $643.6^{* * *}$ \\
\hline & -256.09 & & & -15.92 \\
\hline \multirow[t]{2}{*}{ Child (yes) } & $6337.71^{* * *}$ & 5809.123 & 6866.289 & $401.4^{* * *}$ \\
\hline & -269.69 & & & -16.97 \\
\hline \multirow[t]{2}{*}{ Time diagnosed ${ }^{C}(\geq 10$ years) } & $-11,356.30^{* * *}$ & $-11,967.4$ & $-10,745.2$ & $-742.19^{* * *}$ \\
\hline & -311.79 & & & 73.37 \\
\hline \multirow[t]{2}{*}{ Constant } & $46,693.04^{* * *}$ & $45,804.71$ & $47,581.38$ & $4225^{* * *}$ \\
\hline & -453.24 & & & -5.254 \\
\hline Observations & 153 & & & 153 \\
\hline AIC & 1066 & & & \\
\hline $\mathrm{BIC}$ & 160,793 & & & \\
\hline Log-likelihood & $-81,495$ & & & \\
\hline Deviance & 161,472 & & & \\
\hline
\end{tabular}

Abbreviations: Min wage minimum wage, CD4 CD4 T-cell count, AIC Akaike information criterion, BIC Bayesian information criterion a *** $p<0.01$

b Parentheses show the categories of the independent variables that are included in the estimations. Reference categories are omitted

'Margins command in STATA is unable to produce incremental effects for the variable Timediagnosed. We therefore calculated it by hand following Williams [22] 
older people are more susceptible to infections [24] and have an immunologic response to therapy $[25,26]$, they incur higher medication costs [27].

We also found that health care costs are $\$ 835$ higher on average for females. This finding is consistent with previous works demonstrating that women are more prone to the risks of HIV infection compared to men [28-30]. Prior research also argues that women have better health maintenance compared to men and have greater utilisation of healthcare services [31-34].

Marital and parental status are also associated with higher healthcare costs. Costs are $\$ 644$ higher on average for married people and $\$ 401$ higher on average for people who have children. Earlier studies have shown that the odds of HIV infection are higher for married women [35], as they cannot refuse sex and ask for condom use in marriage [36]. In addition, it is possible to hypothesise that people with children have a higher risk of acquiring infectious diseases.

Socioeconomic status variables include education, wealth and employment status. Care costs are $\$ 1482$ higher on average for employed and $\$ 58$ higher on average for people that are more educated. Since both education and employment indicate a higher socioeconomic status, these people could be better informed and have more access to care services, which would explain higher care costs [37]. Wealth represents the welfare status of an individual (measured by minimum wage, including non-wage income, family support, transfer payments, etc.) and is divided into 3 categories: lower than minimum wage, higher than minimum wage and higher than double minimum wage. Healthcare costs are significantly lower for wealthier people. An implication of this is that people with lower income levels live in communities with lower socioeconomic status and have a higher risk of acquiring infections [38, 39].

Risk factors include sexual orientation, smoking, alcohol use, drug addiction and psychiatric drug use. Of all these, psychiatric drug use and drug addiction are the two major factors that increase healthcare costs. Healthcare costs are $\$ 518$ and \$651 higher on average for patients who are addicted to drugs and who use psychiatric drug(s), respectively. Earlier studies have also demonstrated that drug use is significantly and positively related to HIV sexual risk behaviour [40], and injection drug use is a mode of HIV transmission in many regions including China, the USA, and Russia [41]. In addition, substance users have multiple comorbidities that complicate HIV treatment and prevention [42] and are particularly vulnerable to suboptimal combination antiretroviral therapy (cART) adherence [43].

Smoking and alcohol use are also common risk factors among PLHIV, and they contribute to increased incidence of non-AIDS-related morbidity and mortality [44, 45]. In our sample, smoking status seemed to have a greater impact on costs compared to alcohol use.
Sexual orientation poses another risk factor. In our sample, we found that people who identify themselves as heterosexual have slightly lower healthcare expenditures compared to LGBT people. Homosexual people could be better informed about access to healthcare and thus have higher costs [34]. At the same time, they have riskier sexual behaviour, which increases the prevalence of HIV and sexually transmitted infections (STIs) and thus overall care costs [46-48].

Finally, we consider the duration of treatment. Compared to people who were recently diagnosed with HIV, people who were diagnosed $\geq 10$ years ago have $\$ 743$ lower expenditures on average. This may be due to the improvements in CD4 count with the number of years from diagnosis [31].

\section{Discussion}

This study provides valuable data about the link between socioeconomic factors and the healthcare costs of PLHIV. In addition, we have shown that the findings of our GLM indicate that these socioeconomic parameters and CD4 cell count are the factors significantly related to the healthcare costs of patients. A number of studies show that HAART reduces the average number of annual hospitalisations, and hence results in considerable cost savings [49-51]. But the literature lacks the information regarding PLHIV already on HAART and how other factors, such as socioeconomic, are affecting the healthcare costs of PLHIV. The findings of this study strongly suggest that the healthcare costs of PLHIV is associated with socioeconomic parameters such as age, gender, marital and parental status, time since diagnosis, employment, wealth status and illicit drug use.

Our results confirm the literature [23] on the link between the better health status of the patient decreases healthcare costs. Age has the largest effect on costs in this study. Compared to younger people, older people have higher expenditures. As older people are more susceptible to infections and have an immunologic response to therapy, they incur higher medication costs. Following sources [24-27] also confirm these results. Female healthcare costs are higher as opposed to male health care costs. Prior research also argues that women have better health maintenance compared to men and have greater utilisation of healthcare services [28-34]. Marriage increases the costs; the odds of HIV infection are higher for married women as they cannot refuse sex and ask for condom use in marriage. Earlier studies have supported these results $[35,36]$. Both education and employment indicate a higher socioeconomic status, educated and employed people could be better informed and have more access to care services, which would explain higher care costs [37]. Healthcare costs are significantly lower for wealthier people. An implication of this is that people with lower income levels live in communities with lower socioeconomic status and have a higher risk of acquiring infections [38, 39];. Drug 
use is significantly and positively related to HIV sexual risk behaviour and causes higher costs. In addition, substance users have multiple comorbidities that complicate HIV treatment and prevention and are particularly vulnerable to suboptimal cART adherence. Earlier studies have also supported the link between drug use and HIV costs [4043]. Smoking and alcohol use contribute to increased incidence of non-AIDS-related morbidity and mortality [44, 45]. In our study, smoking status seemed to have a greater impact on costs compared to alcohol use. We found that people who identify themselves as heterosexual have slightly lower healthcare expenditures compared to LGBT people. Homosexual people have higher costs. They are better informed about access to healthcare, they have riskier sexual behaviour, which increases the prevalence of HIV and sexually transmitted infections (STIs) and thus overall care costs are higher [34, 46-48]. The duration of treatment lowers the expenditures. This may be due to the improvements in CD4 count with the number of years from diagnosis [31].

Together, these results provide important insights into the factors that affect healthcare costs of PLHIV. We have demonstrated that in addition to immunological status of patients, socioeconomic variables are important factors that determine costs of PLHIV.

The policy implications of the key factors influencing the healthcare costs of PLHIV are also critical for public policy makers, healthcare workers, health ministries and employment community programs.

This study is not without its limitations. The clinic and the country were not selected at random but they represent the whole country [48]. and as such this is a convenience sample; therefore, some of the estimates may have been over- or underestimated. The proportion of female PLHIV is low compared to male PLHIV. The total sample of PLHIV in our data is small, and this may cause unobserved discrepancies in our results. Costs may vary in other settings depending on drug costs and administrative policies.

\section{Conclusion}

Our results suggest that in addition to immunological status, socioeconomic factors play a substantial role in the healthcare costs of PLHIV.

As expected, a better health status of the PLHIV, measured by $\mathrm{CD} 4$ cell count, decreases healthcare costs but socio-economic factors such as the age, gender, marital and parental status, smoking, alcohol use, time since diagnosis, employment, wealth status, sexual orientation and illicit drug use are also having a crucial role for decreasing the costs of PLHIV.

The key factors influencing the healthcare costs of PLHIV are also critical for public policy makers, healthcare workers, health ministries and employment community programs.

\section{Appendix}

Table 5 GLM Results for Identity and Log Links

\begin{tabular}{|c|c|c|}
\hline & (1) & (2) \\
\hline VARIABLES/LINK & IDENTITY & LOG \\
\hline \multirow[t]{2}{*}{ CD4 (200-499 cells/mm³) } & $-789.194^{* * *}$ & $-0.128^{* * *}$ \\
\hline & -19.659 & -0.004 \\
\hline \multirow[t]{2}{*}{ CD4 ( $\geq 500$ cells $\left./ \mathrm{mm}^{3}\right)$} & $-951.866^{* * *}$ & $-0.172^{* * *}$ \\
\hline & -19.447 & -0.004 \\
\hline \multirow[t]{2}{*}{ Wealth ( $\geq$ min wage) } & $-1270.716^{* * *}$ & $-0.218^{* * *}$ \\
\hline & -17.79 & -0.004 \\
\hline \multirow[t]{2}{*}{ Wealth ( $\geq 2 x$ min wage) } & $-1218.168^{* * *}$ & $-0.219^{* * *}$ \\
\hline & -18.536 & -0.004 \\
\hline \multirow[t]{2}{*}{ Employment (employed) } & $1349.770^{* * *}$ & $0.242^{* * *}$ \\
\hline & -15.413 & -0.004 \\
\hline \multirow[t]{2}{*}{ Education (high school \& university) } & $-33.103^{* * *}$ & $-0.042^{* * *}$ \\
\hline & -12.839 & -0.003 \\
\hline \multirow[t]{2}{*}{ Alcohol (yes) } & $166.506^{* * *}$ & $0.074^{* * *}$ \\
\hline & -14.565 & -0.004 \\
\hline \multirow[t]{2}{*}{ Smoke (yes) } & $435.100^{* * *}$ & $0.110^{* * *}$ \\
\hline & -12.397 & -0.003 \\
\hline \multirow[t]{2}{*}{ Psychiatric drug (yes) } & $581.622^{* * *}$ & $0.078^{* * *}$ \\
\hline & -17.829 & -0.004 \\
\hline \multirow[t]{2}{*}{ Drug addiction (yes) } & $498.590^{* * *}$ & $0.091^{* * *}$ \\
\hline & -14.872 & -0.003 \\
\hline \multirow[t]{2}{*}{ Sexual orientation (heterosexual) } & $106.991^{* * *}$ & $0.090^{* * *}$ \\
\hline & -13.437 & -0.003 \\
\hline \multirow[t]{2}{*}{ Age (40-54) } & $860.885^{* * *}$ & $0.174^{* * *}$ \\
\hline & -14.732 & -0.003 \\
\hline \multirow[t]{2}{*}{ Age $(\geq 55)$} & $1912.262^{* * *}$ & $0.384^{* * *}$ \\
\hline & -23.162 & -0.005 \\
\hline \multirow[t]{2}{*}{ Gender (female) } & $870.202^{* * *}$ & $0.200^{* * *}$ \\
\hline & -19.715 & -0.004 \\
\hline \multirow[t]{2}{*}{ Marriage status (married) } & $723.812^{* * *}$ & $0.199^{* * *}$ \\
\hline & -15.501 & -0.003 \\
\hline \multirow[t]{2}{*}{ Child (yes) } & $343.916^{* * *}$ & $0.058^{* * *}$ \\
\hline & -16.673 & -0.004 \\
\hline \multirow[t]{2}{*}{ Time diagnosed ( $\geq 10$ years) } & $-639.422^{* * *}$ & $-0.095^{* * *}$ \\
\hline & -19.443 & -0.004 \\
\hline \multirow[t]{2}{*}{ Constant } & $3733.697^{* * *}$ & $8.148^{* * *}$ \\
\hline & -28.266 & -0.007 \\
\hline Observations & 153 & 153 \\
\hline AIC & 1077 & 1104 \\
\hline $\mathrm{BIC}$ & 162,532 & 166,695 \\
\hline Log-likelihood & $-82,364$ & $-84,446$ \\
\hline Deviance & 163,211 & 167,374 \\
\hline
\end{tabular}

Abbreviations: Min wage minimum wage, CD4 CD4 T-cell count, AIC Akaike information criterion, BIC Bayesian information criterion 


\section{Abbreviations}

PLHIV: People living with HIV/AIDS; PHIMS: Probel Hospital Information Management System; HAART: Highly Active Antiretroviral Therapy; GLM: Generalised Linear Model; LGBT: Lesbian, Gay, Bisexual, Transgender; OLS: Ordinary Least Squares; CART: Combination Antiretroviral Therapy; STIs: Sexually Transmitted Infections; Min wage: Minimum Wage; CD4: CD4 Tcell count; Std. Dev: Standard deviation; Freq: Frequency; AIC: Akaike Information Criterion; BIC: Bayesian Information Criterion

\section{Acknowledgements}

We are thankful to the participants of All izmir workshop in economics in Izmir for their valuable comments on an earlier draft of the manuscript. The authors acknowledge all the participating patients at the Izmir region of Turkey for their tremendous cooperation.

\section{Authors' contributions}

DÖ, HÖÖ and ST designed the study, DÖ and FNKK analyzed the data. All authors read and approved the manuscript.

\section{Funding}

Not applicable.

\section{Availability of data and materials}

The dataset used and analyzed during the current study are available from the corresponding author on reasonable request.

\section{Ethics approval and consent to participate}

The study was approved by Bozyaka Education and Research Hospital Ethical Committee of the University of Health Sciences. Written informed consent was obtained from all of the participants during the survey.

\section{Consent for publication}

Not applicable.

\section{Competing interests}

The authors declare that they have no competing interests.

\section{Author details}

'Department of Clinical Microbiology and Infectious Diseases, University of Health Sciences, Bozyaka Education and Research Hospital, İmir, Turkey. ${ }^{2}$ Department of Economics, Yaşar University, Üniversite Caddesi No: 37-39, 35040 Bornova, İzmir, Turkey.

\section{Received: 14 November 2019 Accepted: 5 March 2020}

\section{Published online: 20 March 2020}

\section{References}

1. World Health Organization, Global Health Observatory (GHO) data; http:// www.who.int/. Accessed 2 October 2019.

2. Hyduk C, Kustowski K. Helping people coping with HIV and AIDS manage employment. In: Sourcebook of rehabilitation and mental health practice. US: Springer; 2004. p. 417-31.

3. Gökengin D, Türkiye'de HIV. Infeksiyonu: Hedefe Ne Kadar Yakınız? Klimik Dergisi. 2018;31(1):4-10.

4. Sargin F, Yildiz D, Aydin OA, Mete B, Gunduz A, Karaosmanoglu HK, Yemisen M, Yazici Y, Bolukcu S, Durdu B, Senates E, Ozaras R, Dokmetas I, Tabak F. Changes in HIV demographic patterns in a low prevalence population: no evidence of a shift towards men who have sex with men. Int J Infect Dis. 2016;48:52-5.

5. Özdemir HÖ, Tosun S, Özdemir D, Korkmaz E. The determinants of employability of people living with HIV/AIDS in Turkey. Am J Ind Med. 2019. https://doi.org/10.1002/ajim.23056.

6. Tosun S, Aygün O, Özdemir HÖ, Korkmaz E, Özdemir D. The impact of economic and social factors on the prevalence of hepatitis B in Turkey. BMC Public Health. 2018;18(1):649

7. UNAIDS. Global HIV \& AIDS statistics - 2019 fact sheet. https://www.unaids. org/en/resources/fact-sheet Accessed 2 Oct 2019.

8. Probel Hospital Information Management System, (PHIMS) http://en.probel. com.tr/ Accessed 11 February 2020

9. Özdemir D, Özdemir HÖ. Health care cost of socioeconomic inequalities: a pioneering population-wide study. Am J Public Health. 2019;109(6):835-6.
10. Colchero MA, Cortés-Ortiz MA, Romero-Martínez M. HIV prevalence, sociodemographic characteristics, and sexual behaviours among transwomen in Mexico City. Salud Publica Mex. 2015;57:99-106.

11. Kattan JA, Kudish KS, Cadwell BL, Soto K, Hadler JL. Effect of vaccination coordinators on socioeconomic disparities in immunization among the 2006 Connecticut birth cohort. Am J Public Health. 2014;104(1):e74-81. https://doi.org/10.2105/AJPH.2013.301418.

12. Deb P, Norton EC. Modelling health care expenditures and use. Annu Rev Public Health. 2018:39:489-505.

13. Nelder JA, Wedderburn RW. Generalised linear models. J R Statistical Soc Series A (General). 1972:135(3):370-84

14. Hardin JW, Hilbe J. Generalised linear models and extensions. Fourth ed. College Station: Stata press; 2018.

15. McCullagh P, Nelder JA. Generalized linear models. 2nd ed. London: Chapmann Hall; 1989.

16. Box GE, Cox DR. An analysis of transformations. J R Stat Soc Ser B Methodol. 1964:26(2):211-43.

17. Park, R. E. (1966). Estimation with heteroscedastic error terms. Econometrica (pre-1986), 34(4), 888

18. Manning WG, Mullahy J. Estimating log models: to transform or not to transform? J Health Econ. 2001;20(4):461-94.

19. Glick HA, Doshi JA, Sonnad SA, Polsky D. Economic evaluation in clinical trials. 2nd ed. Oxford: Oxford University Press; 2014.

20. Pregibon D. Goodness of link tests for generalised linear models. J R Stat Soc C. 1980;29:15-23.

21. Glick, H., 2008. Methods for cost estimation in CEA: the GLM approach. AcademyHealth, issues in cost-effectiveness analysis. Washington, DC. Found online at: http://www. Uphs. Upenn. Edu/dgimhsr/documents/ acadhlth.Glick, 62208.

22. Williams R. Using the margins command to estimate and interpret adjusted predictions and marginal effects. Stata J. 2012 Jun;12(2):308-31.

23. Dube BNR, Marshall TP, Ryan RP, Omonijo M. Predictors of human immunodeficiency virus (HIV) infection in primary care among adults living in developed countries: a systematic review. Systematic Rev. 2018;7(1):82.

24. Sanders GD, Bayoumi AM, Holodniy M, Owens DK. Cost-effectiveness of HIV screening in patients older than 55 years of age. Ann Intern Med. 2008; 148(12):889-903.

25. Grabar S, Kousignian I, Sobel A, Le Bras P, Gasnault J, Enel P, et al. Immunologic and clinical responses to highly active antiretroviral therapy over 50 years of age. Results from the French hospital database on HIV. Aids. 2004;18(15):2029-38.

26. Stafford KA, Magder LS, Hungerford LL, Guralnik JM, El-Kamary SS, Baumgarten M, Redfield RR. Immunologic response to antiretroviral therapy by age among treatment-naive patients in sub-Saharan Africa. Aids. 2018; 32(1):25-34.

27. Krentz HB, Gill MJ. Increased costs of HIV care associated with aging in an HIV-infected population. HIV Med. 2015;16(1):38-47.

28. Geary CW, Bukusi EA. Women and ARV-based HIV prevention-challenges and opportunities. J Int AIDS Soc. 2014:17:19356.

29. Mastro TD, Sista N, Abdool-Karim Q. ARV-based HIV prevention for womenwhere we are in 2014. J Int AIDS Soc. 2014;17:19154.

30. Kiweewa, F. M., Mugwanya, K. K., \& Kiweewa, F. (2017). Antiretroviral-based HIV pre-exposure prophylaxis for women: recent advances and next steps. HIV/AIDS - contemporary challenges. Nancy Dumais (Ed.), Rijeka, Croatia: InTech, 55-64.

31. Brennan A, Jackson A, Horgan M, Bergin CJ, Browne JP. Resource utilisation and cost of ambulatory HIV care in a regional HIV Centre in Ireland: a microcosting study. BMC Health Serv Res. 2015a;15(1):139.

32. Brennan A, Morley D, O'Leary AC, Bergin CJ, Horgan M. Determinants of HIV outpatient service utilisation: a systematic review. AIDS Behav. 2015b;19(1): 104-19.

33. Ritchwood TD, Bishu KG, Egede LE. Trends in healthcare expenditure among people living with HIV/AIDS in the United States: evidence from 10 years of nationally representative data. Int J Equity Health. 2017: 16(1):188

34. Kupek E, Dooley M, Whitaker L, Petrou S, Renton A. Demographic and socioeconomic determinants of community and hospital services costs for people with HIV/AIDS in London. Soc Sci Med. 1999:48(10):1433-40.

35. Fagbamigbe AF, Adebayo SB, Idemudia E. Marital status and HIV prevalence among women in Nigeria: ingredients for evidence-based programming. Int J Infect Dis. 2016;48:57-63. 
36. Chai X, Sano Y, Kansanga M, Baada J, Antabe R. Married women's negotiation for safer sexual intercourse in Kenya: does experience of female genital mutilation matter? Sex Reprod Healthc. 2017;14:79-84.

37. Aracena B, Gutiérrez JP, Bertozzi SM, Gertler P. Cost of AIDS care in Mexico: what are its main individual predictors? Arch Med Res. 2005;36(5):560-6.

38. Niyonsenga T, Trepka MJ, Lieb S, Maddox LM. Measuring socioeconomic inequality in the incidence of AIDS: rural-urban considerations. AIDS Behav. 2013;17(2):700-9

39. Kalichman S, Katner H, Banas E, Kalichman M. Population density and AIDSrelated stigma in large-urban, small-urban, and rural communities of the southeastern USA. Prev Sci. 2017;18(5):517-25.

40. Booth RE, Kwiatkowski CF, Chitwood DD. Sex-related HIV risk behaviours: differential risks among injection drug users, crack smokers, and injection drug users who smoke crack. Drug Alcohol Depend. 2000;58(3):219-26.

41. Mathers BM, Degenhardt L, Phillips B, Wiessing L, Hickman M, Strathdee SA, et al. Global epidemiology of injecting drug use and HIV among people who inject drugs: a systematic review. Lancet. 2008;372(9651):1733-45.

42. Altice FL, Kamarulzaman A, Soriano V V., Schechter M, Friedland GH. Treatment of medical, psychiatric, and substance-use comorbidities in people infected with HIV who use drugs. Lancet. 2010;376(9738):367-387. Available from: doi: https://doi.org/10.1016/S0140-6736(10)60829-X.

43. Binford MC, Kahana SY, Altice FL. A systematic review of antiretroviral adherence interventions for HIV-infected people who use drugs. Current HIV/AIDS Reports. 2012;9(4):287-312.

44. Giles ML, Gartner C, Boyd MA. Smoking and HIV: what are the risks and what harm reduction strategies do we have at our disposal? AIDS Res Ther. 2018;15(1):26

45. Brown JL, DeMartini KS, Sales JM, Swartzendruber AL, DiClemente RJ. Interventions to reduce alcohol use among HIV-infected individuals: a review and critique of the literature. Current HIV/AIDS Reports. 2013;10(4): 356-70.

46. Osmond DH, Pollack LM, Paul JP, Catania JA. Changes in prevalence of HIV infection and sexual risk behaviour in men who have sex with men in San Francisco: 1997-2002. Am J Public Health. 2007;97(9):1677-83.

47. Dangerfield DT, Smith LR, Anderson JN, Bruce OJ, Farley J, Bluthenthal R. Sexual positioning practices and sexual risk among black gay and bisexual men: a life course perspective. AIDS Behav. 2018:22(6):1919-31.

48. Hess KL, Crepaz N, Rose C, Purcell D, Paz-Bailey G. Trends in sexua behaviour among men who have sex with men (MSM) in high-income countries, 1990-2013: a systematic review. AIDS Behav. 2017;21(10):2811-34.

49. Kockaya G, Zengin TE, Yenilmez FB, Dalgic C, Malhan S, Cerci P, Oksuz E, Unal S. Analysis of the treatment costs of HIV/AIDS in Turkey. Farmeconomia. 2016;17:1.

50. Tatar M, Kockaya G, Ozelgun B, Elbir ZT, Senturk A, Tuna E, Unal S, Tumer A, Inkaya C. Direct cost of Hiv/Aids in Turkey. Value Health. 2016;19(7):A411-2.

51. Tatar M, Kockaya G, Ozelgun B, Elbir ZT, Senturk A, Tuna E, Unal S, Tumer A, Inkaya C. Indirect Cost Of Hiv/Aids: Results of A survey From A Turkish Research Center. Value Health. 2016;19(Issue 7):A411.

\section{Publisher's Note}

Springer Nature remains neutral with regard to jurisdictional claims in published maps and institutional affiliations.

Ready to submit your research? Choose BMC and benefit from:

- fast, convenient online submission

- thorough peer review by experienced researchers in your field

- rapid publication on acceptance

- support for research data, including large and complex data types

- gold Open Access which fosters wider collaboration and increased citations

- maximum visibility for your research: over $100 \mathrm{M}$ website views per year

At $\mathrm{BMC}$, research is always in progress.

Learn more biomedcentral.com/submissions 